\title{
Promoting Sustainability at the Ports through Knowledge Sharing
}

\author{
Bhaskar Kura1, Catherine Dunn², Amrita Iyer'1, Elena Bourbour Ajdari1 \\ ${ }^{1}$ Civil \& Environmental Engineering, University of New Orleans, Louisiana, USA \\ ${ }^{2}$ Port of New Orleans, New Orleans, USA \\ Email: bkura@uno.edu
}

Received February 2014

\begin{abstract}
Ports are a major source of economic activity and environmental pollution. They use a variety of equipment for loading/unloading and movement of cargo, such as marine vessels, cranes, trucks and railroads. These activities can cause large amounts of pollution to the air, water and soil media. Despite the pollution generated, it also serves as a medium for tourism with its cruise liners. This paper discusses port activities and how it effects the environment. The main focus of this paper is Knowledge Sharing for Sustainability of Ports. Sustainability indicators should help in evaluating port conditions and this knowledge sharing among the proposed 10 major world ports should accelerate economic growth and use of latest technologies for pollution reduction.
\end{abstract}

\section{Keywords}

Sustainability; Ports Benefits; Environmental Issues at Ports; Knowledge Sharing

\section{Introduction}

A harbor area such as coastal areas, great lakes and inland river systems where ships load and unload are considered as a port. Ports provide shore side facilities for the transfer of cargo between ships, barges, railroads and trucks. They also have cruise terminals for passengers.

\section{Ports and Its Economic Importance}

In the coastal regions, Ports play a major role for economic growth. Port cities have always been at a higher position in the aspect of economic life for many centuries. More infrastructure, employment and associated services are required as the goods and passengers increase with time. This affects the local and regional economy and environment in many ways. Ports are a crucial connection between sea and land transportation. Ports also serve as a social function by providing jobs to people.

Ports provide benefit for international trade. More than $80 \%$ of cargoes are transported by sea. They serve as global entry point and source of growth with low trade costs for host ports. At the same time, there are some disadvantages associated with it like reducing the attractiveness of the city due to pollution, traffic and noise (OECD, 2014).

About one third of the total worth of global trade is done by the liner shipping industry which is the most effi- 
cient way of goods' transport (WSC, 2014). “In one year, a single large containership might carry over 200,000 container loads of cargo. It would require hundreds of freight aircraft, many miles of railcars, and fleets of trucks to carry the goods that can fit on one large liner ship (WSC, 2014).” In the US (2007) port activity contributed more than \$3.15 trillion to the Gross Domestic Product and 13.3 million port related jobs were generated (AAPA, 2014).

Table 1 lists the top 10 container ports of the world (on the basis of the total volume in 2011 and 2012) and Table 2 lists the top 10 ports of the United States (on the basis of total tons in 2011).

\section{Port Activities}

The activities and operations carried out at any port depend largely on the type and volume of cargo being shipped. The operations related activities are the following:
1) Transportation
2) Cargo handling
3) Building/grounds maintenance
4) Chemical storage and handling
5) Fueling
6) Ship air emissions
7) Painting and paint stripping
8) Rail maintenance
9) Vehicle and equipment maintenance
10) Ship breaking, repair and maintenance

Considering the variety of processes carried by ports and the potential to consume a huge amount of energy and emit large quantities of multi-media pollutants (solid wastes, liquid wastes, and air pollutants), there is a great need for a knowledge-based system to manage environmental affairs of ports around the world. This is particularly important as the mismanagement of port activities and related emissions/waste discharges can impact the community in the immediate vicinity (AAPA, 2014).

\subsection{Pollution from Port Operations}

Enormous engines running on diesel fuel, diesel trucks, trains, cargo handling equipment, cranes and other equipment at ports cause a tremendous impact on the environment which could affect the health of workers and

Table 1. Top 10 ports in the world (World Shipping Council (WSC), 2013).

\begin{tabular}{cccc}
\hline Rank & Port, Country & Volume 2012 (Million TEUs) & Volume 2011 (Million TEUs) \\
\hline 1 & Shanghai, China & 32.53 & 29.94 \\
2 & Singapore, Singapore & 31.65 & 24.38 \\
3 & Hong Kong, China & 23.1 & 22.57 \\
4 & Shenzhen, China & 22.94 & 16.18 \\
6 & Busan, South Korea & 17.04 & 14.72 \\
7 & Ningbo-Zhoushan, China & 16.83 & 14.42 \\
8 & Guangzhou Harbor, China & 14.74 & 13 \\
9 & Qingdao, China & 14.5 & 11.59 \\
\hline
\end{tabular}


Table 2. Top 10 ports in the United States (US Department of Transportation, Bureau of Transportation Statistics, 2013).

\begin{tabular}{|c|c|c|c|c|c|c|c|c|}
\hline \multirow[b]{2}{*}{ Ports } & \multicolumn{2}{|c|}{2011} & \multicolumn{2}{|c|}{2010} & \multicolumn{2}{|c|}{2001} & \multirow{2}{*}{$\begin{array}{c}\text { Percent } \\
\text { change } \\
2010-2011\end{array}$} & \multirow{2}{*}{$\begin{array}{l}\text { Percent } \\
\text { change } \\
\text { 2001-2011 }\end{array}$} \\
\hline & Rank & $\begin{array}{l}\text { Total tons } \\
\text { (Millions) }\end{array}$ & Rank & $\begin{array}{l}\text { Total tons } \\
\text { (Millions) }\end{array}$ & Rank & $\begin{array}{l}\text { Total tons } \\
\text { (Millions) }\end{array}$ & & \\
\hline South Louisiana, LA & 1 & 246.5 & 1 & 236.3 & 1 & 212.6 & $4.3 \%$ & $16.0 \%$ \\
\hline Houston, TX & 2 & 237.8 & 2 & 227.1 & 2 & 185.1 & $4.7 \%$ & $28.5 \%$ \\
\hline New York, NY and NJ & 3 & 139.2 & 3 & 139.2 & 3 & 137.5 & $0.0 \%$ & $1.2 \%$ \\
\hline Long Beach, CA & 4 & 80.3 & 5 & 75.4 & 8 & 67.6 & $6.4 \%$ & $18.7 \%$ \\
\hline New Orleans, LA & 5 & 77.2 & 7 & 72.4 & 4 & 85.6 & $6.6 \%$ & $-9.9 \%$ \\
\hline Beaumont, TX & 6 & 73.7 & 4 & 77.0 & 5 & 79.1 & $-4.3 \%$ & $-6.9 \%$ \\
\hline Corpus Christi, TX & 7 & 70.5 & 6 & 73.7 & 6 & 77.6 & $-4.2 \%$ & $-9.1 \%$ \\
\hline Los Angeles, CA & 8 & 65.0 & 8 & 62.4 & 14 & 51.4 & $4.2 \%$ & $26.5 \%$ \\
\hline Huntington-Tristate & 9 & 58.6 & 9 & 61.5 & 7 & 76.7 & $-4.8 \%$ & $-23.6 \%$ \\
\hline Baton Rouge, LA & 10 & 57.9 & 13 & 55.5 & 10 & 61.4 & $4.2 \%$ & $-5.8 \%$ \\
\hline
\end{tabular}

local communities (NRDC, 2014). All the activities mentioned above may not be performed at every port; also each activity will not generate the same amount of pollution at every port. Table $\mathbf{4}$ gives the pollutant information and their pathways for the sub activities mentioned in Table 3 (Dunn et al., 2011).

\subsection{Air Pollution}

Major air pollutants from diesel engines at ports are particulate matter (PM), volatile organic compounds (VOCs), nitrogen oxides $\left(\mathrm{NO}_{\mathrm{x}}\right)$, and sulfur oxides $\left(\mathrm{SO}_{\mathrm{x}}\right)$. Percentage emissions of $\mathrm{NO}_{\mathrm{x}}$ and $\mathrm{PM}_{10}$ from various Port activities are shown in Figure 1. In addition to these pollutants, there are other air pollutants like carbon monoxide (CO), formaldehyde, heavy metals, dioxins, and pesticides. These pollutants may cause asthma, other respiratory diseases, lung cancer, cardiovascular disease, and premature death. Therefore, reduction of pollutant emissions and improvement of air quality in the vicinity of ports is one of the major environmental concerns and needs to be managed (NRDC, 2014).

\subsection{Water Pollution}

Dirty water from ships may be directly dumped into the sea or leached into it, which affects the water quality and causes problems to the human health and to the life of marine species. It causes a decrease in oxygen level, accumulation of toxins in fish and degrading aquatic life. At the hull of a ship water gets contaminated with oil called as Bilge. It must be cleaned and emptied regularly to prevent contamination by hazardous vapors. Bilge along with other wastes from the ship poses a serious threat to aquatic life. Port water used by ships is called Ballast water, stored in tanks. Ballasting is important for cargo loading and unloading activities and improves stability. To prevent the growth of marine organisms on ships, antifouling additives are used in paints. These are mixed with paints and coated on ship surface, which are toxic in nature (NRDC, 2014). AFS Treaty prohibits the use of antifouling agents like organotins and tributyltin (TBT) given the fact that they are harmful to the marine environment (AAPA, 2014).

There are international and national regulations for vessel discharge which need to be followed accurately to prevent irreparable environmental damages.

\section{Concept of Knowledge Sharing}

The University of New Orleans (UNO) is using the Port of New Orleans as a case study to develop/propose a user friendly intelligent application to promote sustainability at ports. This will be achieved by team work which 
Table 3. Typical processes and sub-activities at a typical port (AAPA, 1998).

\begin{tabular}{|c|c|}
\hline Major Process & Sub Activity Numbers* \\
\hline \multicolumn{2}{|l|}{ CONSTRUCTION ACTIVITIES } \\
\hline Building Demolition & D2, O5,O6, O7, O11, O12 \\
\hline Building Renovation & D1, D2, O5,O6, O7, O11, O12 \\
\hline Bulkhead Installation & D1, D3, O5,O6, O7, O9, O11, O12 \\
\hline Contamination Remediation & D1, O5,O6, O7, O11, O12 \\
\hline Dredge Material Disposal & O5,O6, O7, O9, O11, O12, O13, O14 \\
\hline Dredging & O5,O6, O7, O9, O11, O12, O13, O14 \\
\hline Landfilling & D1, O5,O6, O7, O11, O12 \\
\hline New Building Construction & D1, O5,O6, O7, O11, O12 \\
\hline Pavement Installation & D1, O5,O6, O7, O11, O12 \\
\hline Pavement Removal & D1, O5,06, O7, O11, 012 \\
\hline Pier \& Dock Construction & D1, D3, O5,O6, O7, O9, O11, O12 \\
\hline Site Clearing & D1, O5,O6, O7, O11, O12 \\
\hline Utility Construction & D1, O5,O6, O7, O11, O12 \\
\hline \multicolumn{2}{|l|}{ OPERATIONS ACTIVITIES } \\
\hline \multicolumn{2}{|l|}{ Automobile Transport Operations } \\
\hline - Offloading & O1, O2, O6, O11 \\
\hline - Storage & O1, O2, O6, O11, O12 \\
\hline Building and Grounds Maintenance/Landscaping & D1,D2, O2, O5, O6, O7, O8, O11, O12 \\
\hline \multicolumn{2}{|l|}{ Cargo Handling } \\
\hline - Dry Bulk & O3, O14 \\
\hline - Liquid Bulk & O4,O5, O6, O14 \\
\hline - General Cargo & O3, O5, O14 \\
\hline - Containers & O3, O5, O14 \\
\hline - Breakbulk & O3, O5, O14 \\
\hline Chemical Storage and Handling & O4, O5, O6 \\
\hline \multicolumn{2}{|l|}{ Fueling } \\
\hline - On-Loading & O4, O6 \\
\hline - Storage & O4, O6 \\
\hline - Off-Loading & O4, O6 \\
\hline \multicolumn{2}{|l|}{ Painting } \\
\hline - Anti-Fouling-Building & $\mathrm{O} 2, \mathrm{O} 5$ \\
\hline - Service Vehicles & $\mathrm{O} 2, \mathrm{O} 5$ \\
\hline Paint Stripping & O2, O5, O13, O15 \\
\hline \multicolumn{2}{|l|}{ Public Access and Recreation } \\
\hline - Cruise Lines & O5, O6, O7, O9, O10, O13, O14 \\
\hline - Fishing Piers & O5, O6, O7, O9, O10, O13, O14 \\
\hline - Moorings/Slips & O5, O6, O7, O9, O10, O13, $\mathrm{O} 14$ \\
\hline - Public Recreational Access & D1, O5, O6, O7, O9, O10, O13, O14 \\
\hline Rail Maintenance & D1, D2, D3, O2, O5, O6, O11, O12 \\
\hline \multicolumn{2}{|l|}{ Ship liquid discharges } \\
\hline - Ballast Water & O5, O8, O9, O11, O13 \\
\hline
\end{tabular}




\section{Continued}

\begin{tabular}{l|l}
\hline \multicolumn{1}{l}{ - Tank Cleaning } & O5, O8, O9, O11, O13 \\
\hline $\begin{array}{l}\text { - Bilge Water } \\
\text { - Sewage }\end{array}$ & O5, O8, O9, O11, O13 \\
\hline $\begin{array}{l}\text { Solid Waste } \\
\text { - Ship-Generated }\end{array}$ & O8, O9, O9, O11, O13 \\
\hline $\begin{array}{l}\text { - Shore-Generated } \\
\text { Vehicle and Equipment Maintenance }\end{array}$ & O8, O9 \\
\hline Vessel Repair and Maintenance & O5, O6, O7, O8, O10, O11, O12, O13 \\
Ship Breaking & D2, O5, O6, O7, O8, O10, O11, O12, O13 \\
\hline
\end{tabular}

* Table 4 contains details of sub activity numbers.

Table 4. List of sub activities and potential pollutants (AAPA, 1998).

\begin{tabular}{|c|c|c|c|}
\hline No. & Sub Activity Name & Potential Pollutants & Target Pathways \\
\hline D1 & Sediment and Erosion Control & Sediments, Dust & Surface water, Air \\
\hline D2 & Buildings Renovation and Demolition & $\begin{array}{l}\text { Asbestos, Lead, Dust, Sediments, } \\
\text { Petroleum Hydrocarbons, PCBs }\end{array}$ & Surface water, Air, Soil, Groundwater \\
\hline D3 & Bulkhead, Pier, and Dock Construction & Sediments & Surface water \\
\hline $\mathrm{O} 1$ & Automobile Storage and Transport & $\begin{array}{l}\text { Oil, Grease, Sediments, Soaps, Combustion } \\
\text { By-Products }\end{array}$ & Air, Surface water \\
\hline $\mathrm{O} 2$ & Building and Grounds Maintenance & $\begin{array}{l}\text { Pesticides/Herbicides/Fertilizers, Oil and } \\
\text { Grease, Sediments }\end{array}$ & Groundwater, Surface water, Air, Soil \\
\hline $\mathrm{O} 3$ & Bulk Storage and Handling_-Dry & Dust, Sediment, Metals, Hydrocarbons, Salts & Surface water, Air, Soil \\
\hline $\mathrm{O} 4$ & Bulk Storage and Handling__Liquid & $\begin{array}{l}\text { Oil and Grease, Fuels, Organic Chemicals, } \\
\text { Inorganic Chemicals }\end{array}$ & Air, Surface water, Groundwater, Soil \\
\hline O5 & Chemical Storage and Handling-Non Bulk & $\begin{array}{c}\text { Organic Chemicals, Inorganic Chemicals, } \\
\text { Metal, Oil and Grease }\end{array}$ & Surface water, Air, Groundwater, Soil \\
\hline O6 & Fueling & Petroleum Hydrocarbons & Groundwater, Surface water, Air \\
\hline O7 & $\begin{array}{l}\text { Vessel and Equipment Painting and } \\
\text { Paint Stripping }\end{array}$ & $\begin{array}{l}\text { Paints, Solvents/Hydrocarbons, } \\
\text { Metals, Solids }\end{array}$ & Surface water, Soil, Air \\
\hline O8 & $\begin{array}{c}\text { Ship and Shore generated Solid Waste } \\
\text { Handling }\end{array}$ & $\begin{array}{c}\text { Oils and Grease, Petroleum Hydrocarbons, } \\
\text { Metals, Solvents, Paints }\end{array}$ & Surface water, Soil \\
\hline O9 & $\begin{array}{l}\text { Protection of Marine Mammals and } \\
\text { Sensitive Aquatic Habitats }\end{array}$ & & \\
\hline $\mathrm{O} 10$ & Public Access and Recreation & $\begin{array}{l}\text { Solvents, Petroleum Hydrocarbons, } \\
\text { Metals, Solid Waste }\end{array}$ & Surface water \\
\hline O11 & Vehicle and Equipment Maintenance & $\begin{array}{l}\text { Oils and Grease, Petroleum Hydrocarbons, } \\
\text { Coolants, Solvents }\end{array}$ & Surface water, Air, Soil \\
\hline $\mathrm{O} 12$ & Vehicle and Equipment Washing & $\begin{array}{c}\text { Oils and Grease, Petroleum Hydrocarbons, } \\
\text { Surfactants/soaps }\end{array}$ & Surface water \\
\hline $\mathrm{O} 13$ & Vessel Repair and Maintenance & $\begin{array}{l}\text { Oils and Grease, Paints, Solvents, } \\
\text { Fuels, Sediments }\end{array}$ & Surface water, Air \\
\hline $\mathrm{O} 14$ & Ship Air Emissions & $\mathrm{NO}_{\mathrm{x}}, \mathrm{SO}_{2}$, Particulates, HAPs & Air \\
\hline $\mathrm{O} 15$ & Ship Breaking & $\begin{array}{l}\text { Oils and Grease, Heavy Metals, Suspended } \\
\text { Solids, PCBs, Asbestos }\end{array}$ & Surface water, Soils, Air \\
\hline
\end{tabular}




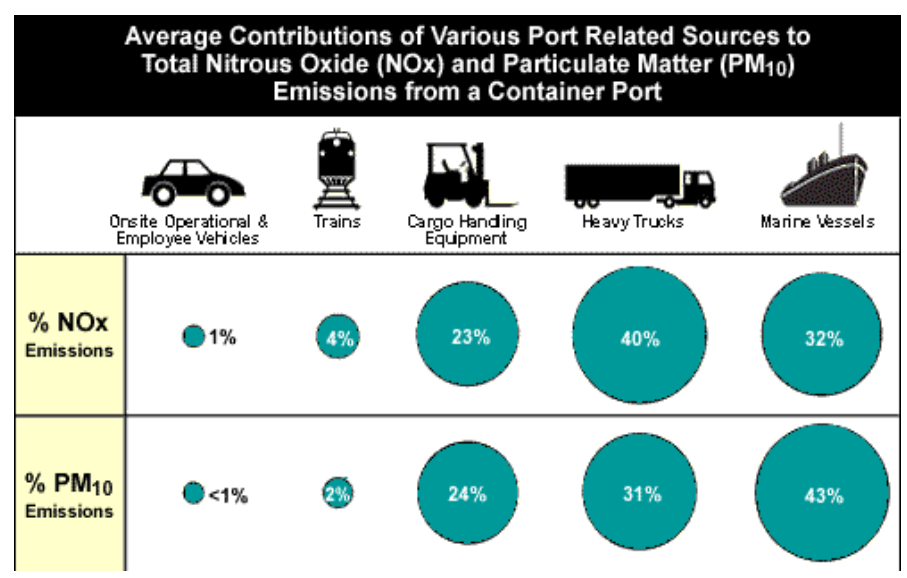

Figure 1. $\mathrm{NO}_{\mathrm{x}}$ and $\mathrm{PM}_{10}$ emissions from various port related activities.

includes Civil \& Environmental Engineering graduate students, faculty, Computer Science students, and the personnel of the Port of New Orleans. The results and products of this research and application can be applied to all ports to improve and manage environmental quality in our surroundings in a better way. Figure 2 depicts the concept of this research.

\section{Methodology of Building a Knowledge-Based (KB) System for Promoting Sustainability at Ports}

Process being used by UNO Researchers to quantify the pollution load from the ports and create a knowledgebase for promoting sustainability:

- Collaborate with the Port of New Orleans to understand the processes in detail.

- Benchmark pollution loads (multimedia pollutants (air, water, solid).

- Identify sustainability indicators important for the Ports.

- Calculate the real time values for the identified indicators for The Port of New Orleans.

- Survey ten major ports to understand the indicators for other ports using the online system.

- Design and develop knowledge-sharing methodology to improve performance of participating ports.

Different environmental indicators should be considered for ports sustainability such as energy consumption, water consumption and discharge from vessels, sanitary wastewater from cruise liners and offices, solid and hazardous wastes, air pollution, diesel power, fueling, painting, and welding. Other indicators like employment potential, secondary economic impacts and tertiary economic impacts will be considered as cost indicators which have a critical role for managing and quality improvement. The UNO application or knowledge-based system will use data from participating ports on a 5 - 10 year scale in computing indicators in useful units. For instance, energy consumption can be calculated as Energy used/100,000 tons of cargo, Energy used/100,000 barrels of crude, or Energy used/1000 $\mathrm{ft}^{2}$ of the building space (office or warehouse). In the same way, other indicators can be calculated and analyzed. In addition, UNO application aims to adopt EPA and international regulations/guidelines to evaluate participating Ports and provide rational recommendations that are environmentally—sensible, economically-viable, and socially-responsible.

Authors believe that the proposed Knowledge-Based (KB) System (Web-Based) can be accessed by the consortium of ports under the leadership of MERIC, which will promote "sustainability" by reducing pollution load, increasing profitability, and improving social relevance.

\section{Conclusion}

Every country has its national and international sector of transportation, in which a major role is played by ocean-going and inland waterways. They are classified as cargo and passenger vessels. As mentioned in this paper, Ports have potential to produce large amounts of pollution. The amount of pollution can be a function of the amount of fuel consumed; work done, quantity of materials handled, types of materials handled, design of the Port and its logistics, Port equipment, and more. Different ports around the world have various technologies, 


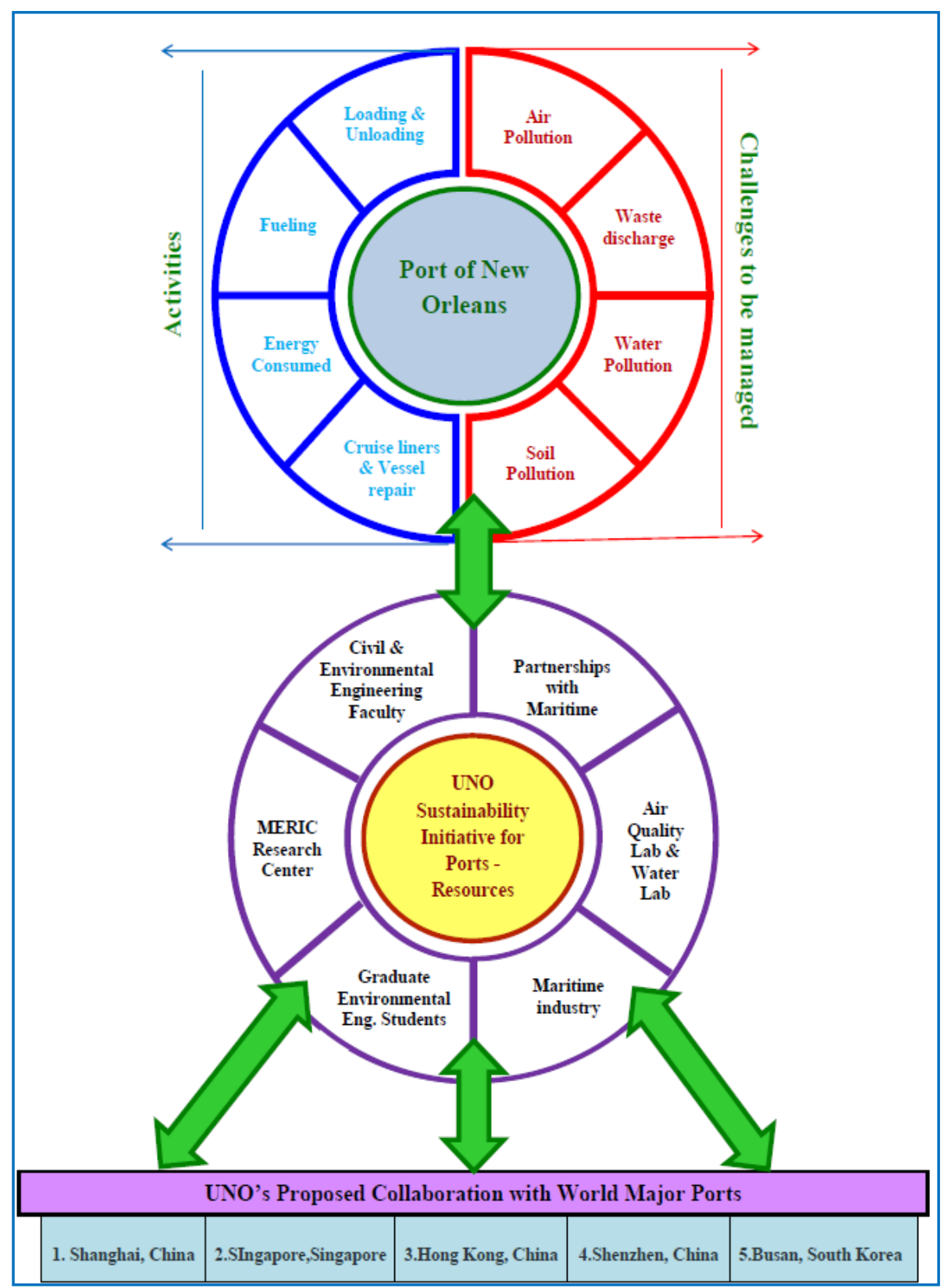

Figure 2. Knowledge sharing using KB system for promoting sustainability at ports.

equipment and logistics for their day-to-day operations and pollution control. The goal of this project is to combine the knowledge available at MERIC-UNO and the World Ports on a single platform, like a web-based application (KB System) which will be accessible to users to implement technologies and strategies to reach the goals of sustainability in an efficient manner. This is achieved by identification of sustainability indicators for ports and benchmarking them. The study will use and compare these indicators with other major ports in the world to attain sustainability through knowledge-sharing to promote growth. The KB System to be developed is aimed to improve Port performance, reduce costs, improve profitability, and protect the public health \& the environment.

\section{References}

AAPA (American Association of Port Authorities) (2014). Trade and Economic Growth. 
http://www.aapa-ports.org/Industry/content.cfm?ItemNumber=1024

American Association of Port Authorities (AAPA) (1998). Environmental Management Handbook.

Association of Port Authorities (AAPA) (2014).

http://www.aapaports.org/Industry/?navItemNumber=494

Compliance Monitoring (2014).

http://www.epa.gov/compliance/monitoring/programs/cwa/npdes.html

Dunn, C., Verma, S. and Kura, B. Environmental Management of Port Activities: A Case Study of Port of New Orleans, \#2011-A-267-AWMA.

NRDC (2004). Harboring Pollution, Strategies to Clean up US Ports.

OECD (2014). Green Growth and Sustainable Development.

http://www.oecd.org/greengrowth/portshowtogetmorevalueformoney.htm

United States Department of Transportation (2014). Research and Innovative Technology Administration, Bureau of Transportation Statistics.

http://www.rita.dot.gov/bts/sites/rita.dot.gov.bts/files/publications/national_transportation_statistics/html/table_01_57.html

US Environmental Protection Agency (2009). Current Methodologies in Preparing Mobile Source Port-Related Emission Inventories, Final Report.

US Environmental Protection Agency (EPA). National Pollutant Discharge Elimination System.

World Shipping Council (WSC) (2014).

http://www.worldshipping.org/benefits-of-liner-shipping 